\title{
Staffing analysis of the regional motor transport complex (by the case of the Orenburg region)
}

\author{
Nicolay Yakunin ${ }^{1 *}$, Natalya Yakunina $^{1}$, Vitaliy Kotov $^{1}$ and Olga Kabanova ${ }^{1}$ \\ ${ }^{1}$ Orenburg state university, 13 Pobeda avenue, Orenburg, Russian Federation, 460018
}

\begin{abstract}
The article defines the quantitative staff characteristics of road transport and vehicles of economic entities of various organizational and legal forms and departmental subordination. The dependences of the personnel number on the vehicles number were obtained, which made it possible to determine the need for the motor complex of the Orenburg region in labor resources, also the share of road transport workers in the total structure of the working population was determined. The work establishes the values of the staffing characteristics of motor transport enterprises, taking into account the levels of education and forms of ownership, which made it possible to determine the need for the motor transport complex of the Orenburg region in personnel.
\end{abstract}

\section{Introduction}

Road transport is essential for the sustainable development of the country's economy and social sphere. Over $60 \%$ of all passengers and significant transportation of goods in urban, suburban, intercity and international communications are transported by this mode of transport. Road transport has unique advantages over other transport modes, primarily in terms of mobility, the ability to carry out the transport correspondence "from door to door" and over the "last mile". At the same time, the cost of such transportation per unit of transported objects often exceeds the cost of transportation by other transport modes. The accident rate remains high. The main efforts should be focused on improving the efficiency and safety of this type of transport.

Road transport is a complex multi-level system with the decentralized management based on the use of legal and technical regulations. A feature of this mode of transport is its use in all sectors of the national economy - from industry, construction, agriculture to public transport. This circumstance makes it impossible to use the existing official statistical data to assess the current state of staffing in the motor transport complex. In these documents the information is given on the main types of enterprises activities in which road transport is significant but auxiliary. In this regard, there is a need to determine the current state of staffing of road transport activities without any separation based on industry.

A special role is assigned to staffing in improving road transport activities. The staff competence and its ability to create conditions for sustainable development, to carry out main and auxiliary activities are the conditions for successful development. There are

\footnotetext{
* Corresponding author: yakunin-n@yandex.ru
} 
scientific and methodological works that are aimed at improving the management of labor productivity in road transport [1-5]. There are known works that study the influence of personnel and their qualifications on the production process $[6,8-12,15]$, including works that reflect the experience of the world's leading economies [7, 13]. In these works, the influence of the economic activity structure in the country regions on the characteristics of road transport enterprises is noted, among which the greatest attention is paid to the number of such enterprises, the number and standard size of vehicles within the structure and other indicators. At the same time, it is proposed to determine the personnel characteristics by methods that do not take into account the changes in economic relations in the country, technical, technological and organizational innovations caused by scientific and technological progress. The dependence of the personnel number in motor transport activities on the vehicles number remains unexplored.

In addition, the relevance of assessing the current state of staffing of road transport activities is due to the need to form an enrolment under the programs of training specialists "Engineering and technology of land transport." There is no understanding of the need for training specialists in various administrative and territorial entities of the country without such an assessment.

The aim of the research is to substantiate the characteristics of staffing in road transport activities to determine the share of road transport workers in the overall structure of the working-age population and then to predict the need for labor resources. To achieve the goal, it is necessary to solve the following tasks:

1 to determine the quantitative staff characteristics of road transport and vehicles of economic entities of various organizational and legal forms and departmental subordination;

2 to determine the dependence of the personnel number on the vehicles number;

3 using certain dependencies to determine the number of road transport employees in the region and their share in the total structure of the working-age population.

For the research the Orenburg region was chosen by the authors' group. The total fleet $(N)$ of buses and trucks in the Orenburg region in 2018 amounted to 136.7 thousand units, which is the 13th place in the Russian Federation and the 3rd place among the regions of the Volga Federal District [14].

The scientific novelty of the research is:

1 the quantitative staff characteristics of road transport and vehicles of economic entities of various organizational and legal forms, without taking into account their departmental subordination;

2 the dependence of the personnel number on the vehicles number, which made it possible to determine the need of the motor transport complex of the Orenburg region in labor resources;

3 the share of road transport employees in the total structure of the working-age population in the Orenburg region.

\section{Theoritical and methodological approach}

The number of employees of the motor transport complex in the constituent entities of the Russian Federation is determined in an enlarged form by the dependence

$$
\mathrm{N}_{\text {Tot }}=\mathrm{N}_{\mathrm{FP}}+\mathrm{N}_{\mathrm{PC}}+\mathrm{N}_{\text {Oth }}
$$

where, $\mathrm{N}_{\mathrm{FP}}$ - the number of employees of the motor transport complex involved in the enterprises engaged in freight and passenger transportation, persons;

$\mathrm{N}_{\mathrm{PC}}$ - the number of employees of the motor transport complex involved in the maintenance stations of passenger cars, persons; 
$\mathrm{N}_{\text {Oth }}$ - the number of other employees in the field of road transport who are not accounted for in the first and second groups ( $5 \%$ of their total number), persons.

The number of employees $\left(\mathrm{N}_{\mathrm{FP}}\right)$ of the motor transport complex involved in the enterprises engaged in freight and passenger transportation.

The methods of mathematical statistics, the theory concepts of the cars technical operation are used in this work as the main ones. The questionnaire method was used to determine the number of employees $\left(\mathrm{N}_{\mathrm{FP}}\right)$ involved in the enterprises engaged in freight and passenger transportation. In the questionnaire, it was necessary to indicate the information about the number of rolling stock, the total number of employees of the motor transport enterprise (MTE) with an indication of their total number, specialists with higher education and specialists with profile motor transport education. The survey involved 60 enterprises of the Orenburg region, among which 30 enterprises had the organizational and legal form as a legal entity and 30 were individual entrepreneurs. The main type of these enterprises activity was chosen in an arbitrary way and generally reflected the structure of the economic activity of the Orenburg region. These enterprises provided services for the passengers' transportation by buses, goods transportation by trucks, trailers and semitrailers. The survey was conducted anonymously, without specifying the name of the legal entity and individual entrepreneur.

The following indicators were used in the work.

The number Z of MTE employees per unit of MTE rolling stock:

$$
\mathrm{z}=\frac{\mathrm{NEmpl}}{\mathrm{NRs}}
$$

where $\mathrm{N}_{\mathrm{Empl}}$ - the total number of MTE employees, persons;

$\mathrm{N}_{\mathrm{Rs}}$ - the number of MTE rolling stock, units.

The number of $\mathrm{z}_{\mathrm{HE}}$ specialists with higher education in MTE per unit of rolling stock:

$$
\mathrm{Z}_{\mathrm{HE}}=\frac{\mathrm{NEmpl} \mathrm{HE}}{\mathrm{NRs}}
$$

where $\mathrm{N}_{\mathrm{Empl} \mathrm{HE}}$ - the number of MTE employees with higher education, persons

The number of $Z_{\text {Prof }}$ specialists with profile road transport education in the MTE per unit of rolling stock:

$$
\mathrm{Z}_{\text {Prof }}=\frac{\mathrm{N}_{\text {Prof }}}{\text { NRs }}
$$

where $\mathrm{N}_{\text {Prof }}$ - the number of specialists with profile road transport education in the MTE, persons

The number of employees of the motor transport complex in the region involved in the enterprises engaged in freight and passenger transportation is determined by the dependence:

$$
\mathrm{N}_{\mathrm{FP}}=\mathrm{M} \cdot \mathrm{N} \text {, }
$$

where $\mathrm{M}$ - mathematical expectation of the Z number of MTE employees per unit of rolling stock, person/unit;

$\mathrm{N}$ - the fleet of buses and trucks in the Orenburg region, units.

The number of $\mathrm{N}_{\mathrm{FP} \mathrm{HE}}$ specialists with higher education working in the motor transport complex in the region and the number of $\mathrm{N}_{\mathrm{FP}}$ Prof specialists with profile motor transport education in the region are determined similarly to dependence (5).

The number of $\mathrm{N}_{\mathrm{PC}}$ employees of the motor transport complex involved in the maintenance stations of passenger cars.

Labor intensity [17] of $\mathrm{T}_{\mathrm{M}-\mathrm{R}}$ works on the maintenance and repair of passenger cars registered in the region: 


$$
\mathrm{T}_{\mathrm{M}-\mathrm{R}}=\frac{\mathrm{N}_{\mathrm{PC}} \cdot \mathrm{L}_{\mathrm{Ann}} \cdot \mathrm{t}_{\mathrm{C}}}{1000}
$$

where $\mathrm{N}_{\mathrm{PC}}$ - the number of passenger cars in the region, units;

$\mathrm{L}_{\mathrm{Ann}}-$ average annual mileage of one passenger car, km;

$t_{c}-$ correction factor (for passenger cars - 2.7).

The number [17] of $\mathrm{N}_{\mathrm{M} . \mathrm{RW}}$ repair workers for the maintenance and repair of passenger cars is determined by the dependence:

$$
\mathrm{N}_{\mathrm{M} . \mathrm{RW}}=\frac{\mathrm{T}_{\mathrm{M}-\mathrm{R}}}{\mathrm{C}_{\mathrm{W}}},
$$

where $\mathrm{C}_{\mathrm{W}}$ - annual time fund of one full-time worker (equal to 1832 hours), hour.

The number of $\mathrm{N}_{\mathrm{M} . \mathrm{HE}}$ specialists [17] with higher education involved in the system of maintenance and repair of passenger cars is from 10 to $20 \%$ of the number of $\mathrm{N}_{\mathrm{M} . \mathrm{RW}}$ repair workers for the maintenance and repair. We accept that

$$
\mathrm{N}_{\text {M.HE }}=0,15 \cdot \mathrm{N}_{\text {M.RW, }}
$$

and the total number of $\mathrm{N}_{\mathrm{PC}}$ employees of the motor transport complex involved in the service stations of passenger cars is determined by the dependence

$$
\mathrm{N}_{\mathrm{PC}}=\mathrm{N}_{\mathrm{M} . \mathrm{HE}}+\mathrm{N}_{\mathrm{M} . \mathrm{RW}}
$$

The number of $\mathrm{N}_{\text {Tot.HE }}$ specialists with higher education in the region, who are not included in the first and second groups

$$
\mathrm{N}_{\text {Tot.HE }}=1,05 \cdot\left(\mathrm{N}_{\mathrm{FP} \mathrm{HE}}+\mathrm{N}_{\mathrm{M} . \mathrm{HE}}\right)
$$

The share of $\mathrm{P}$ workers of road transport in the total structure of the working-age population in the Orenburg region is determined by the dependence

$$
\mathrm{P}=\frac{N_{T o t}}{Q} \cdot 100 \%
$$

where Q - the working-age population. (In the Orenburg region the working-age population was $1,206,375$ people in 2018).

\section{Research}

The total number of rolling stock was 5453 units and 11119 people were employed in the surveyed economic entities. In these enterprises, the number of rolling stock ranged from 3 to 292 units, while in the structure of legal entities - from 49 to 292 units, in the structure of individual entrepreneurs - from 3 to 89 units. The average number of $\mathrm{N}_{\mathrm{RS}}$ rolling stock in all enterprises was 118 units, while for legal entities this indicator is equal to 148 units, for individual entrepreneurs - 36 units (Table 1).

In the enterprises under study, the number of $\mathrm{Z}$ employees per unit of rolling stock ranged from 1.09 to 2.84 people with mathematical expectation of 2.02 people per car. At the same time, for legal entities this indicator was 2.0, for individual entrepreneurs - 2.04 (Table 1).

The number of MTE employees with higher education per unit of rolling stock ranged from 0 to 0.71 . The average value of this indicator in the Orenburg region was 0.21 (Table $1)$.

The number of MTE employees with profile motor transport education per unit of rolling stock took a value from 0 to 0.33 (Table 1). The average value of this indicator in the Orenburg region was 0.08 . At the same time, for legal entities -0.10 , for individual entrepreneurs - 0.06. It was found that for most legal entities this indicator reached 0.19, 
and for individual entrepreneurs - up to 0.10. This fact indicated that at MTE with the status of a legal entity there are more personnel with profile road transport education than individual entrepreneurs.

Table 1.The obtained values of staffing indicators of motor transport enterprises of the Orenburg region.

\begin{tabular}{|c|c|c|c|c|}
\hline Type of enterprise & \multicolumn{4}{|c|}{ Indicators } \\
\cline { 2 - 5 } & $\begin{array}{c}\text { The number of } \\
\text { rolling stock } \\
\text { (expectation } \\
\text { value) }\end{array}$ & $\begin{array}{c}Z \\
\text { (expectation } \\
\text { value) }\end{array}$ & $\begin{array}{c}Z_{\mathrm{HE}} \\
\text { (expectation } \\
\text { value) }\end{array}$ & $\begin{array}{c}\text { Z } \\
\text { (expectation } \\
\text { value) }\end{array}$ \\
\hline All enterprises & $3-292(118)$ & $1,09-2,84(2,02)$ & $0-0,71(0,21)$ & $0-0,33(0,08)$ \\
\hline Legal entities & $49-292(148)$ & $1,09-2,84(2,00)$ & $0,04-0,43(0,18)$ & $0,06-0,19(0,10)$ \\
\hline $\begin{array}{c}\text { Individual } \\
\text { entrepreneurs }\end{array}$ & $3-85(36)$ & $1,41-2,42(2,04)$ & $0-0,71(0,23)$ & $0-0,33(0,06)$ \\
\hline
\end{tabular}

The dependences of the MTE employees number on the rolling stock number have been obtained. The value of the approximation reliability according to the obtained dependences was not less than 0.72 . The number of MTE employees, specialists with higher education and profile employees according to the dependencies presented in Figures 1-3, increases with increased number of the rolling stock fleet.

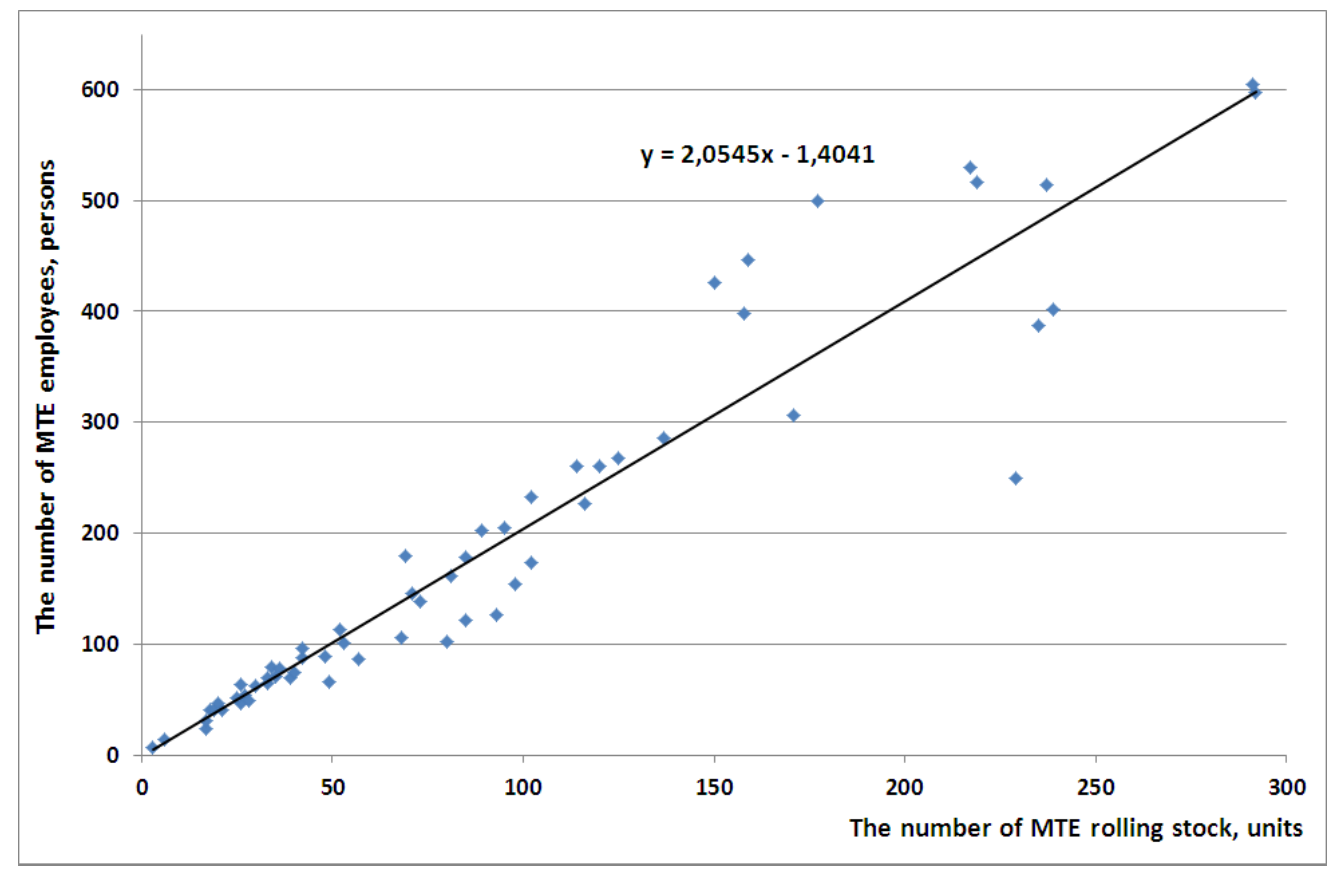

Fig. 1. The dependence of the total number of MTE employees on the number of rolling stock 


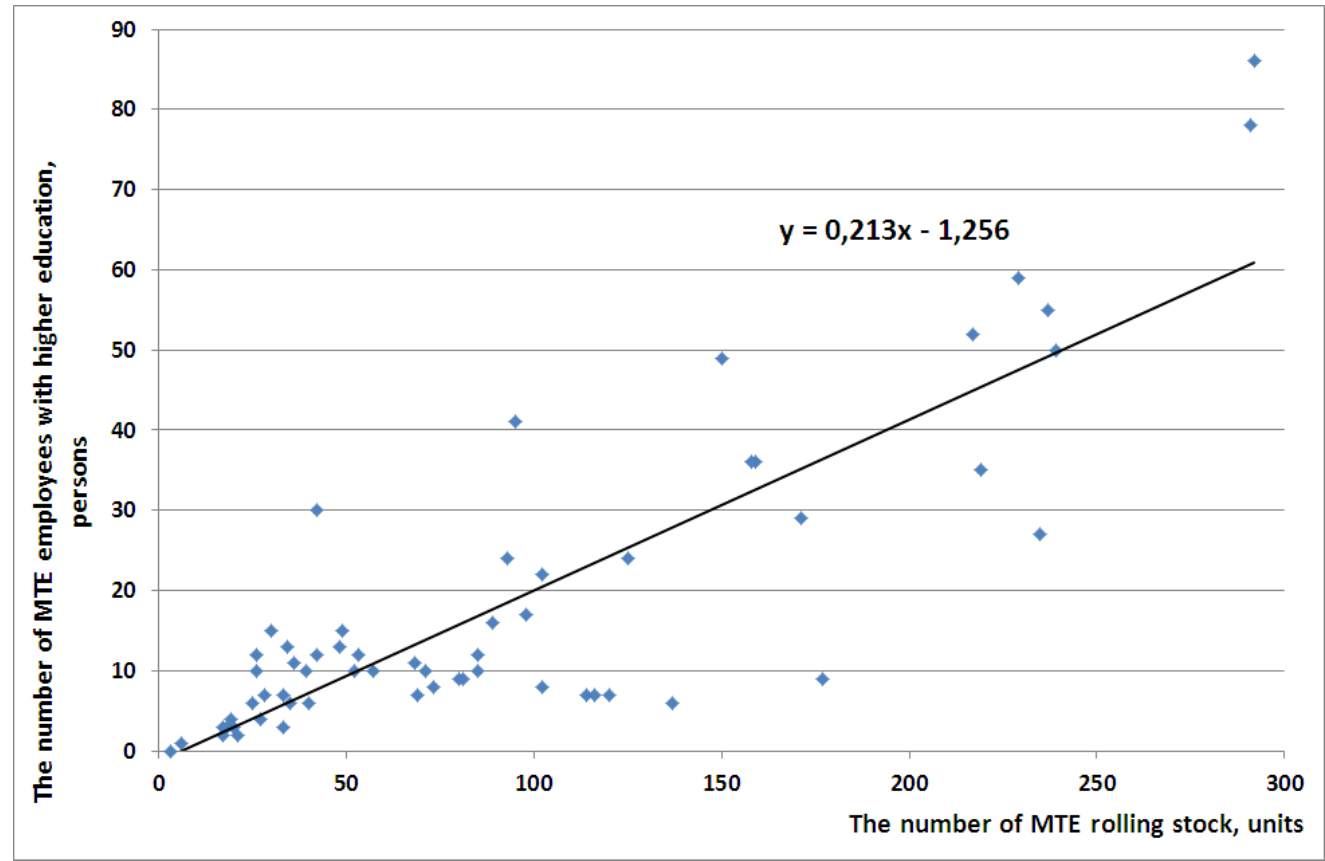

Fig. 2. The dependence of the number of MTE employees with higher education on the number of rolling stock

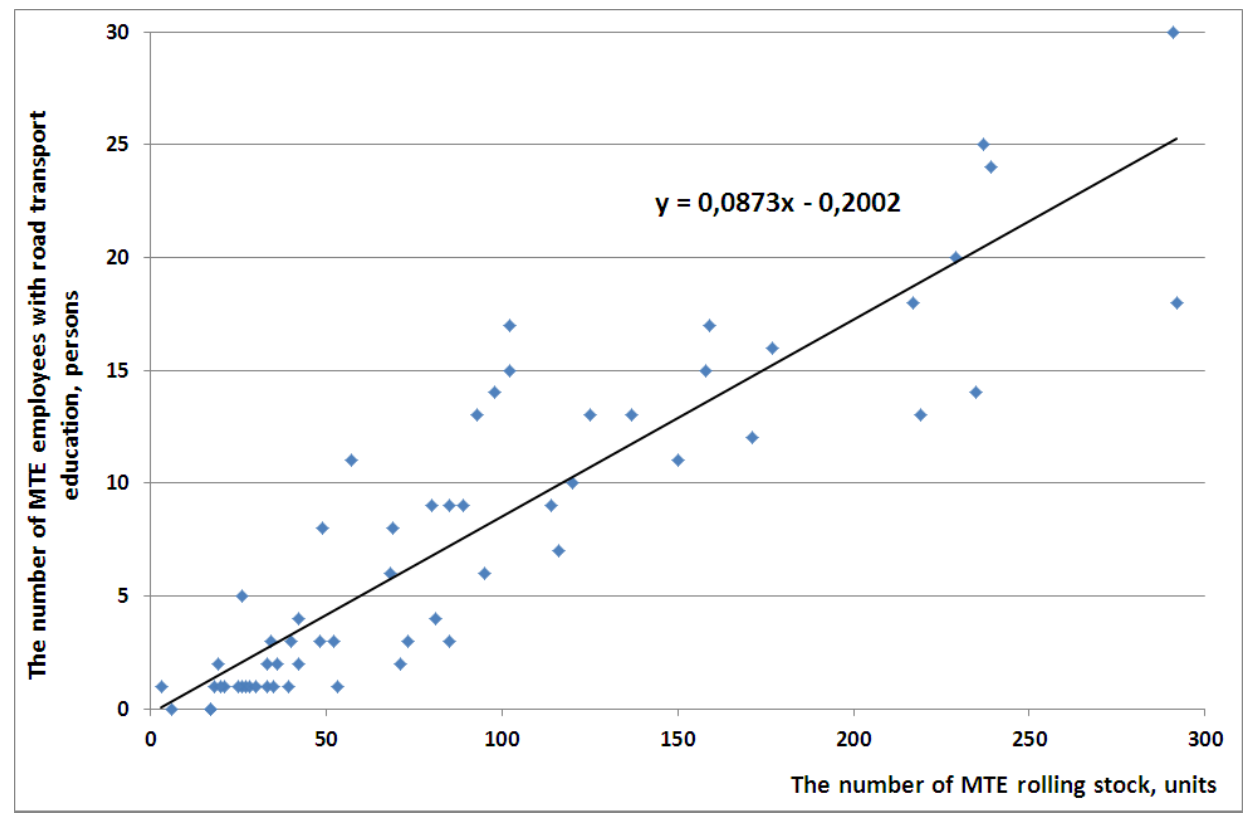

Fig.3. The dependence of the number of MTE employees with profile education on the number of rolling stock

The dependencies presented in Figures 1-3 allow determining the need for MTE staffing. 
The working-age population in the Orenburg region amounted to $1,206,375$ people in 2018 [14].

If there are 2.02 employees per unit of vehicle (trucks and buses) and the number of buses and trucks in the Orenburg region was 136.7 thousand units, then 276.1 thousand employees $\left(\mathrm{N}_{\mathrm{FP}}\right)$ should be involved in the motor transport complex of the Orenburg region.

The number of passenger cars registered in the Orenburg region was 716.7 thousand units [14], the average annual mileage of a passenger car in the Orenburg region was 16 thousand $\mathrm{km}$ [16], then the labor intensity of maintenance and repair of the passenger cars fleet, $\mathrm{T}_{\mathrm{M}}-\mathrm{T}_{\mathrm{R}}$ will be:

$$
\mathrm{T}_{\mathrm{M}-\mathrm{R}}=716700 * 16000 * 2,7 / 1000=30961440 \text { standard hours; }
$$

The employees number of the motor transport complex involved in the service stations of passenger cars will be:

$$
\mathrm{N}_{\mathrm{PC}}=30961440 / 1832=16,9 \text { thousand people. }
$$

The number of other road transport workers who are not included in the first two groups will be:

$$
\begin{aligned}
& \mathrm{N}_{\text {Oth }}=(276,1+16,9) * 0,05=14,7 \text { thousand people } \\
& \mathrm{N}_{\text {Tot }}=276,1+16,9+14,7=307,7 \text { thousand people }
\end{aligned}
$$

Thus, the total number of employees of the motor transport complex of the Orenburg region is 307.7 thousand employees, that is $25.5 \%$ of the working population of the region. At the same time, the estimated number of specialists with profile road transport education in the Orenburg region should be 10,936 people.

\section{Results and conclusion}

The comparison of the calculated number of employees of the motor transport complex in the region, established in this study, and the same indicator given in annual statistical compilations, indicate their discrepancy. The calculated value is 4.2 times higher than the statistical one. This difference is due to the fact that statistical compilations reflect the information in the context of industries and does not take into account the activities of road transport in their structure. This situation makes it impossible to use existing official statistics to assess the current state of staffing. In addition, the obtained results help to understand the need for labor resources for the transport authorities of the regions, especially that part which has the competence of organizers and technologists of road transport activities.

The share of road transport workers is $25.5 \%$ in the total structure of the working-age population of the Orenburg region. The comparison of this indicator with similar indicators in other industries suggests the prevalence of road transport personnel in the structure of the working population. The estimated number of specialists with profile road transport education in the Orenburg region is 10,936 people. Taking into account this fact, it is necessary to determine the directions of labor resources training.

The indicator of the rolling stock number in the road transport enterprises without taking into account the organizational and legal form of activity has significantly decreased in comparison with the Soviet period. The main role in such regression belongs to legal entities that existed with a monopoly at that time. It is necessary to note a significant strengthening of the position of individual enterprises as a feature of the current state of economic entities in terms of the rolling stock number. As a result of such multidirectional 
development, a common area of indicator values was formed, which can be regarded as a condition for transforming the form of individual entrepreneurship into the form of a legal entity.

The analysis of the average number indicator of personnel per unit of rolling stock indicates its insignificant differences in the studied organizational and legal forms of enterprises. However, in terms of the MTE employees number with profile road transport education per unit of rolling stock, it should be noted that its average value for legal entities is almost two times higher than that for individual entrepreneurs. This feature, in our opinion, is caused by the fact that legal entities traditionally develop their enterprises not only in the direction of commercial exploitation, but also in the direction of technical exploitation of cars. So far, individual entrepreneurs have just begun to form their production and technical base, and many of them use the services of technical car service on the basis of legal entities. In addition, it should be noted that complicating the structural design of the vehicles, methods of technical service, logistic and organizational support of the transport process put forward increasing demands on managers and specialists of road transport. This is an additional condition for attracting specialists with profile road transport education to work at the MTE.

The study proposes a method for determining the need for staffing of a motor transport enterprise on the example of the Orenburg region, depending on the vehicles number. The values of the staffing characteristics of the motor transport enterprises are determined, taking into account the levels of education and forms of ownership.

\section{References}

1. Bronshtein, L.A. The economics of road transport: a textbook for university students studying in the specialty "Automobiles and Automotive Industry". Moscow: Transport, 349 p. (1976)

2. Bednyak, M.N. Theoretical foundations of a comprehensive solution to the problem of organizing internal production processes of technical operation of vehicles. $\mathrm{PhD}$ thesis. Kiev: Kadi, 112 p. (1980)

3. Kleiner, B.S. Car maintenance and repair. Organization and management. Moscow: Transport, 251 p. (2009)

4. Klotchkov, I.D. Training improving of skilled workers. Moscow: MADI, 90 p. (1974)

5. Kononova, G.A. Socio-economic problems of the working personnel movement of road transport enterprises (based on the research materials at enterprises in Moscow and Yerevan). PhD thesis. Moscow: MADI, 186 p. (1971)

6. Gunin, V.N. Innovation management: a modular program for managers. Organization development management. Moscow: INFRA-M, 328 p. (2008)

7. Zhuravlyov, P.V. World experience in personnel management: Review of foreign sources. Yekaterinburg: Business book, 232 p. (2008)

8. Zhao, TR. Study of Human Resource Management Benefits, Human resources management in the knowledge economy era, Vols I And II, Univ Jinan, Jinan, peoples $r$ china oct 24-25, pp. 947-952 (2009)

9. Sojka, L., Trends and Challenges in Human Resources Management in the New Millennium, management 2016: international business and management, domestic particularities and emerging markets in the light of research, 6th International Scientific Conference on International Business and Management, Domestic Particularities and Emerging Markets in the Light of Research, Slovakia, Sep 29-oct 02, 162-168 pp., (2016) 
10. Strohmeier, S., Digital human resource management: A conceptual clarification, German Journal Of Human Resource Management-Zeitschrift Fur Personalforschung, Volume 34, Issue 3, 345-365pp.

11. Meirinhos, VA, Couto, AI, Societal Human Resources Management and Development, innovation management and education excellence vision 2020: from regional development sustainability to global economic growth, vols I - VI, 27th International Business Information Management Association Conference, Milan, ITALY, MAY 0405, pp. 1584-1587 (2016)

12. Parter, T.S. Improving the system for the formation and the use of skilled workers. $\mathrm{PhD}$ thesis. Moscow: MIManagement, 196 p. (1981)

13. Tatarnikov, A.N. Personnel management in corporations in the USA, Japan, Germany. Moscow: Business, 220 p. (2006)

14. Federal State Statistics Service. Available at: https://rosstat.gov.ru/folder/23455?print=1

15. Yakunina, N.V. \& Yakunin, N.N. \& Menshikh, O.M. \& Gribkov, K.V. The influence of the status of the organizational and technological system on the safety of passenger transportation by road transport. Automobile industry, No. 1. pp. 20-24. 2018.

16. Regulation of the Central Bank of the Russian Federation No. 432-P from September 19, 2014 "About a unified methodology for determining the expenses amount for the refurbishment in relation to a damaged vehicle."

17. Masuyev, M.A. Design of road transport enterprises: textbook for students of higher education establishments. Moscow: Publishing center "Academy”, 244 p. (2007) 